\title{
THE ROLE OF INTAKE OF ENERGY, PROTEIN AND PARENTING WITH NUTRITION STATUS OF AGE 12 - 24 MONTHS IN SOUTHERN MERUYA, WEST JAKARTA
}

\author{
Indra Restu Kurniawan ${ }^{1}$, Nanang Prayitno², Indah Kusumaningrum², \\ Sugeng Wiyono ${ }^{2}$ Meilinasari $^{2}$ \\ ${ }^{1}$ Universitas Muhammadiah Prof DR. Hamka Jakarta \\ ${ }^{2}$ Jurusan Gizi Politeknik Kesehatan Kemenkes Jakarta II \\ E-mail:nprayitno@rocketmail.com
}

\begin{abstract}
Age 0-24 months is a period of rapid growth and development so often called the golden period as well as the critical period. The problem of growth disorders in infants and children under two years (baduta) needs to be addressed seriously. Therefore, every baby and child 12-24 months of age must get nutrition in accordance with their needs. The purpose of this study was to determine the role of energy intake, protein intake and parenting patterns with nutritional status of children aged 12-24 months in Meruya Selatan Village, West Jakarta. Cross Sectional research design. Population 400 toddlers. Sampling in this research using Stratified Random Sampling technique. The sample was 200 respondents. The study showed that the average energy intake of toddlers was 989.18 Calories. Most intake of fat is enough that is 69,5\% (139 balita) while fat intake is included in less category that is $30,5 \%$ (61 under five). Most of the pattern of care in the good category that is $83 \%$ ( 166 children under five), while for not good category that is $17 \%$ (34 children under five). There was a relationship between energy intake $(\mathrm{p}=0,000, \mathrm{r}=-0.290)$, fat intake $(\mathrm{p}=0.049 ; \mathrm{r}=0.139)$, parenting pattern $(\mathrm{p}=0.036 ; \mathrm{r}=-0.148)$ with nutritional status of children aged 12-24 months in Meruya Selatan Village, West Jakarta. There is a relationship between energy intake, fat intake and parenting pattern with nutritional status of children aged 12-24 months in Meruya Selatan Village, West Jakarta.
\end{abstract}

Keywords: Energy Intake, Parenting Patterns , Nutrition Status.

\section{PERAN ASUPAN ENERGI, ASUPAN PROTEIN DAN POLA ASUH DENGAN STATUS GIZI BALITA USIA 12 - 24 BULAN DI KELURAHAN MERUYA SELATAN, JAKARTA BARAT}

\begin{abstract}
ABSTRAK
Usia 0-24 bulan merupakan masa pertumbuhan dan perkembangan pesat sehingga sering disebut dengan periode emas sekaligus periode kritis. Masalah gangguan tumbuh kembang pada bayi dan anak usia dibawah dua tahun (baduta) merupakan masalah yang perlu ditanggulangi dengan serius. Oleh karena itu, setiap bayi dan anak usia 12-24 bulan harus memperoleh gizi sesuai dengan kebutuhannya. Tujuan dari penelitian ini untuk mengetahui peran asupan energi, asupan protein dan pola asuh dengan status gizi balita usia $12-24$ bulan di Kelurahan Meruya Selatan, Jakarta barat. Desain penelitian Cross Sectional. Populasi 400 balita. Pengambilan sampel dalam penelitian ini menggunakan teknik Stratified Random Sampling. Sampel berjumlah 200 responden. Hasil penelitian menunjukkan bahwa Rata-rata asupan energi balita adalah 989,18 Kalori. Sebagian besar asupan lemak balita cukup yaitu 69,5\% (139 balita) sedangkan asupan lemak yang masuk dalam kategori kurang yaitu 30,5\% (61 balita). Sebagian besar pola asuh dalam kategori baik yaitu 83\% (166 balita), sedangkan untuk kategori tidak baik yaitu 17\% (34 balita). Ada hubungan antara asupan energi ( $p=0,000 ; \mathrm{r}=-0,290)$, asupan lemak $(p=0,049 ; \mathrm{r}=0,139)$, pola asuh $(p=0,036 ; \mathrm{r}=-0,148$ dengan status gizi balita usia $12-24$ bulan. dengan status gizi balita usia 12-24 bulan di Kelurahan Meruya Selatan, Jakarta Barat. Hal ini dapat disimpulan bahwa terdapat hubungan antara asupan energi, asupan lemak dan pola asuh dengan status gizi balita usia 12-24 bulan di Kelurahan Meruya Selatan, Jakarta Barat.
\end{abstract}

Kata Kunci : Asupan Energy, Pola asuh Status Gizi. 


\section{PENDAHULUAN}

Usia 0-24 bulan merupakan masa pertumbuhan dan perkembangan pesat sehingga sering disebut dengan periode emas sekaligus periode kritis. Masalah gangguan tumbuh kembang pada bayi dan anak usia dibawah dua tahun (baduta) merupakan masalah yang perlu ditanggulangi dengan serius. Usia dibawah dua tahun merupakan masa yang sangat penting sekaligus masa kritis dalam proses tumbuh kembang bayi baik fisik maupun kecerdasan. Oleh karena itu, setiap bayi dan anak usia 12-24 bulan harus memperoleh gizi sesuai dengan kebutuhannya. Hasil survei menunjukkan bahwa salah satu penyebab terjadinya gangguan tumbuh kembang bayi dan anak usia 12-24 bulan di Indonesia adalah rendahnya mutu makanan pendamping air susu ibu (MP-ASI) dan tidak sesuai pola asuh yang diberikan sehingga beberapa zat gizi tidak dapat mencukupi kebutuhan khususnya energi dan zat gizi lainnya.(1)

Status gizi adalah cerminan ukuran terpenuhinya kebutuhan gizi yang didapat dari asupan dan penggunaan zat gizi oleh tubuh. Status gizi dapat ditentukan dengan pemeriksaan klinis,pengukuran antropometri analisis biokimia, dan riwayat gizi.

Secara nasional, prevalensi berat badan kurang pada tahun 2013 adalah 19,6 persen, prevalensi pendek secara nasional tahun 2013 adalah 37,2 persen, prevalensi sangat kurus secara nasional tahun 2013 masih cukup tinggi yaitu 5,3 persen. (2)

Energi sangat dibutuhkan manusia untuk mempertahankan hidup guna menunjang proses pertumbuhan dan melakukan aktivitas sehari-hari. Ketidakseimbangan masukan energi dengan kebutuhan, bila terjadi pada bayi dan anak-anak yang berlangsung jangka waktu yang lama akan menghambat pertumbuhan, penurunan daya tahan tubuh terhadap penyakit infeksi dan menimbulkan masalah kesehatan.

Lemak merupakan salah satu komponen makanan multifungsi yang sangat penting untuk kehidupan, yaitu sebagai sumber energi, bagian dari membran sel, mediator aktivitas biologis antar sel, isolator dalam menjaga keseimbangan suhu tubuh, pelindung organ-organ tubuh serta pelarut vitamin A, D, E, dan K (3).

Menurut Wahyuning (4) pola asuh adalah seluruh cara perlakuan orang tua yang ditetapkan pada anak, yang merupakan bagian penting dan mendasar menyiapkan anak untuk menjadi masyarakat yang baik. Pengasuhan anak menunjuk pada pendidikan umum yang ditetapkan pengasuhan terhadap anak berupa suatu proses interaksi orang tua (sebagai pengasuh) dan anak (sebagai yang diasuh) yang mencakup perawatan, mendorong keberhasilan dan melindungi maupun sosialisasi yaitu mengajarkan tingkah laku umum yang diterima oleh masyarakat.

\section{METODE PENELITIAN}

Penelitian ini dilakukan di Kelurahan Meruya Selatan, Jakarta Barat dan dilaksanakan pada bulan Juli 2015 Agustus 2015. Penelitian ini dilakukan dengan menggunakan desain cross sectional dengan metode pendekatan deskriptif analitik. Populasi penelitian ini adalah balita usia 12- 24 bulan pengunjung Posyandu di Kelurahan Meruya Selatan yaitu sebanyak 400 balita, sedangkan sampel pada penelitian ini yaitu sebanyak 200 balita. Teknik pengambilan sampel menggunakan Stratified Random Sampling dengan cara jumlah sampel dibagi total posyandu 
Tabel 1 Distribusi asupan energi, asupan protein dan pola asuh

\begin{tabular}{ccccc}
\hline Variabel & Mean & SD & $\begin{array}{c}\text { Minimal - } \\
\text { Maksimal }\end{array}$ & $95 \%$ CI \\
\hline Asupan & 989,18 & 151,92 & $646-1391$ & $967,96-$ \\
Energi & & & & 1010,33 \\
Asupan & 30,18 & 7,25 & $20-63$ & $37,17-39,19$ \\
$\begin{array}{c}\text { Lemak } \\
\text { Pola Asuh }\end{array}$ & 86,63 & 16,68 & $27,3-100$ & $84,30-88,95$ \\
\hline
\end{tabular}

\section{HASIL ANALISIS UNIVARIAT}

Sampel pada penelitian ini sebanyak 200 responden. Asupan energi balita terendah 646 kalori dan yang tertinggi 1391 kalori. Sedangkan rata-rata asupan energi balita adalah 989,18 kalori. Asupan lemak yang terendah 20 gram dan yang tertinggi 63 gram. Sedangkan rata-rata asupan lemak balita adalah 30,18 gram. Skor pola asuh yang terendah bernilai 27,3 dan yang tertinggi bernilai 100 Hasil analisis didapatkan rata-rata skor pola asuh bernilai 86,63 . Untuk lebih jelasnya dapat dilihat pada Tabel 1.

Hasil distribusi frekuensi asupan lemak sebagian besar asupan lemak balita cukup

yaitu 69,5\% (139 balita) sedangkan asupan emak yang masuk dalam kategori kurang yaitu 30,5\% (61 balita). ebagian besar pola asuh dalam kategori baik yaitu 83\% (166

Tabel 2 Distribusi frekuensi asupan lemak dan pola asuh

\begin{tabular}{ccc}
\hline Variabel & n & \% \\
\hline Asupan Lemak & & \\
Cukup & 139 & 69,5 \\
Kurang & 61 & 30,5 \\
Pola Asuh & & \\
$\quad$ Baik & 166 & 83 \\
$\quad$ Tidak baik & 34 & 17 \\
Status Gizi & & \\
$\quad$ Normal & 198 & 99 \\
Gemuk & 2 & 1 \\
\hline
\end{tabular}

balita), edangkan untuk kategori tidak baik yaitu 17\% (34 balita). Lihat Tabel 2.

\section{ANALISIS BIVARIAT}

Tabel 3 menunjukkan analisis Bivariat menggunakan uji korelasi Rank Spearman menunjukkan ada hubungan antara asupan energi $(p=0,000 ; \mathrm{r}=-0,290)$, asupan lemak $(p=0,049 ; \mathrm{r}=0,139)$, pola asuh $(p=0,036$; $\mathrm{r}=-0,148$ dengan status gizi balita usia 1224 bulan.

Tabel 3 Hubungan asupan energi, asupan lemak dan pola asuh dengan status gizi balita usia 12-24 bulan

\begin{tabular}{lccc}
\hline & \multicolumn{3}{c}{ Status Gizi } \\
\hline & n & p & r \\
\hline Asuan Energi & 200 & 0,000 & 0,290 \\
Asuan Lemak & 200 & 0,049 & 0,139 \\
Pola Asuh & 200 & 0,036 & 0,148 \\
\hline
\end{tabular}

\section{HASIL DAN PEMBAHASAN}

Rata-rata asupan energi balita adalah 989,18 kkal, Sebagian besar asupan lemak balita kategori cukup yaitu $69,5 \%$. Sebagian besar pola asuh dalam kategori baik yaitu $83 \%$, hal ini sejalan dengan peneliti sebelumnya Lubis, 2008.(5)

Hasil analisis dalam penelitian ini menunjukkan ada hubungan antara asupan energi dengan status gizi balita usia 12-24 bulan. Hasil ini menyatakan bahwa ada hubungan antara asupan energi dengan status gizi balita usia 1-5 tahun. Asupan energi kurang dari kebutuhan dalam jangka waktu lama akan menghambat 
pertumbuhan, bahkan mengurangi cadangan energi dalam tubuh hingga terjadi keadaan gizi kurang maupun buruk. Hal ini berdampak pada gangguan pertumbuhan fisik, mempunyai badan lebih pendek, mengalami gangguan perkembangan mental dan kecerdasan terhambat.

Hasil analisis dalam penelitian ini menunjukkan ada hubungan antara asupan lemak dengan status gizi balita usia 12-24 bulan. Saat tubuh kekurangan lemak, persediaan lemak akan kurang sehingga tubuh menjadi kurus. Terjadi pula kekurangan asam lemak essensial, yaitu asam lemak linoleat dan linolenat. Kekurangan linoleat menyebabkan pertumbuhan menurun, kegagalan reproduktif, perubahan struktur kulit dan rambut serta patologi hati. Kekurangan asam lemak omega 3 menyebabkan penurunan kemampuan belajar (6).

Hasil analisis dalam penelitian ini menunjukkan ada hubungan antara pola asuh dengan status gizi balita usia 12-24 bulan. Menurut Wahyuning (4) pola asuh adalah seluruh cara perlakuan orang tua yang ditetapkan pada anak, yang merupakan bagian penting dan mendasar menyiapkan anak untuk menjadi masyarakat yang baik. Pengasuhan anak menunjuk pada pendidikan umum yang ditetapkan pengasuhan terhadap anak berupa suatu proses interaksi orang tua (sebagai pengasuh) dan anak (sebagai yang diasuh) yang mencakup perawatan, mendorong keberhasilan dan melindungi maupun sosialisasi yaitu mengajarkan tingkah laku umum yang diterima oleh masyarakat.

Adanya hubungan antara pola asuh dengan status gizi anak usia 12-24 bulan dalam penelitian ini yaitu ibu sudah mengetahui tentang menu makanan yang sesuai dengan Pedoman Gizi Seimbang (PGS) dan ibu dapat menciptakan suasana yang menyenangkan pada saat anak makan. Bila anak tidak mau makan, ibu dapat membujuk agar anak mau menghabiskan makanannya. Pengetahuan ibu tentang kebersihan dalam menyiapkan makanan baik hal ini dapat dilihat dari ibu yang selalu mencuci tangan sebelum mengolah atau memasak bahan makanan dan selalu mencuci alat makan sebelum dipakai.

\section{SIMPULAN DAN SARAN}

Rata-rata asupan energi balita adalah 989,18 kalori. Sebagian besar asupan lemak balita cukup yaitu 69,5\% (139 balita) sedangkan asupan lemak yang masuk dalam kategori kurang yaitu 30,5\% (61 balita). Sebagian besar pola asuh dalam kategori baik yaitu 83\% (166 balita), sedangkan untuk kategori tidak baik yaitu 17\% (34 balita). Terdapat hubungan antara asupan energi, asupan lemak dan pola asuh dengan status gizi balita usia 12-24 bulan. Masih ditemukan anak balita dengan status gizi gemuk, kemungkinan yang terjadi karena pada penelitian ini ditemukannya asupan lemak yang tinggi sehingga disarankan agar mengurangi makanan yang mengandung lemak tinggi seperti makanan yang di goreng, makanan cepat saji, dll.

Kepada ibu yang sudah menerapkan pola pengasuhan anak seperti praktek pemberian makan yang sudah baik diharapkan agar tetap mempertahankannya dan untuk pola asuh nya masih kurang diharapkan agar ibu lebih memperhatikan kembali anak nya dalam praktek pemberian makan seperti menyiapkan makanan untuk anak.

\section{DAFTAR PUSTAKA}

1. Depkes, RI. Kebijaksanaan Departemen Kesehatan tentang Peningkatan Pemberian Air Susu Ibu (ASI) Pekerja Wanita. Pusat Kesehatan Kerja, Departemen Kesehatan Republik Indonesia, Jakarta; 2005 
2. Badan Penelitian dan Pengembangan Kesehatan. Riset Kesehatan Dasar (RISKESDAS 2013). Jakarta: Kementerian Kesehatan Republik Indonesia; 2013

3. Lengu, A. Faktor - Faktor Yang Mempengaruhi Status Gizi Pada Baduta Usia 7 - 24 Bulan Di Kecamatan Riung Barat, Golewa dan BajawaKabupaten Ngada-NTT. Jakarta : Universitas Indonesia; 2013

4. Wahyuning, W. Mengenalkan moral kepada anak. Jakarta: IKAPI; 2003

5. Lubis, R. Hubungan Pola Asuh Ibu Dengan Status Gizi Anak Balita Di

Wilayah Kerja Puskesmas Pantai Cermin Kecamatan Tanjung Pura Kabupaten Langkat. Universitas Sumatra Utara: Medan; 2008

6. Dewi, N. Nutrition and food, gizi keluarga. Jakarta: Penerbit Buku Kompas; 2010 